\title{
Austrian and Dutch Education under Exumination
}

Austria and the Netherlands have recently had their education policies laid bare by teams of examiners from the Organization for Economic Cooperation and Development. These examinations, although founded on facts which are now rather out of date, highlight many of the problems currently being faced by other industrial countries whose education systems have grown in a haphazard manner and who are now attempting to supply industry with enough trained manpower, while at the same time trying to give every child the same opportunity, regardless of his economic or social background $(O E C D$ Reviews of National Policies for Education: Austria, HMSO, $11 \mathrm{~s} ;$ OECD Reviews of National Policies for Education: Netherlands, HMSO, 15s).

One of the chief and inescapable factors influencing the development of education in Austria is the difficulty of transportation in mountain regions, where schools are often very small. The primary education sector has borne the full effects of this situation, which has given rise to regional disparities in educational opportunity. At the age of ten, pupils either remain at primary schools or transfer to grammar schools or vocational schools. For those who remain, there are essentially two types of education--either they continue to be taught by one teacher for all subjects, or they are taught by specialized teachers. The latter system provides the better education, but it is only practical in large schools and pupils in small primary schools in the mountains therefore often tend to miss out on opportunities to transfer to grammar schools or to go to university.

It is in the grammar schools, which select their students by entrance examination, that the chief expansion has taken place during the past few years. The OECD examining team points out, however, that not only are grammar school students predominantly middle class, but that the system has several other weaknesses. For one thing, there is seldom any transfer of pupils from other schools to grammar schools and educational choices made at age ten therefore tend to dictate a child's future to an unhealthy extent. Professor Westley, a member of the OECD examining team, pointed out during the so-called "confrontation meeting"--a discussion between the examining team and the education authorities-that this situation at least calls for adequate parental and pupil guidance when educational choices are made. Dr L. Wohlgemuth, of the Austrian Ministry of Education, defended the extension of the grammar school system on the grounds that it is preferred by parents.

When it came to looking at the universities, the OECD examiners seemed to be on familiar ground. Their analysis of the Austrian higher education system is both more searching and more specific than their analysis of other parts of the education system. They single out five points of weakness. Firstly, 20 per cent of students in Austrian universities come from outside Austria. This, the examiners suggest, tends to inflate the higher education budget to an undesirable extent. A second area which "would appear to warrant examination" is the length of degree courses. The actual study time is at least one third longer than the average time spent at universities in most countries. Financial aid to university students should also be put at a realistic level, the examiners suggest, to remove the need for many students to take employment during their studies, and a closer check should be kept on their academic progress, especially by introducing more examinations and other tests.

Finally, a factor which makes the production of graduates an expensive process for the Austrian economy is that many graduates leave the country soon after qualifying. A conservative estimate has put the proportion of engineers who emigrate at about 10 per cent. The examiners, however, do not offer any solutions to the problem of the brain drain.

The Netherlands, like Austria, has a tripartite secondary education system which gives a distinct advantage to children from middle class backgrounds. The OECD examiners point out that "the historical trend of the distribution of pupils among the various types of schools in the Netherlands shows the distribution to be determined more by social class than by the ability of the child". Again, the examiners noted the lack of opportunity to transfer from one type of secondary school to another, and, despite the device of a "bridge year" to stream students in secondary education, the examiners were not satisfied that selection procedures are sufficiently objective. The bridge year, however, "is a great improvement on such drastic selection methods as the original English ' 11 + examination" ".

Mr J. H. Groesheide, State Secretary, Ministry of Education and Sciences, told the OECD examiners at the confrontation meeting that the concepts embodied in the Dutch education act of 1962 do not preclude "nor do they infer the necessity" to establish comprehensive schools. He predicted, however, that many school boards will soon take the opportunity to estab. lish such schools, because there is a growing interest in comprehensive education in the Netherlands.

In the Netherlands, as in most industrialized countries, the universities are undergoing an unprecedented growth, but Professor Janssen, chairman of the Netherlands Academic Council, said that there are many reasons to reconsider the structure and curricula of the Dutch university system. In particular, the rapidly increasing number of students seeking university places, the long duration of the studies, the high dropout rate, the manpower demands of society and the rising costs of higher education all demand some change in the university system; but for Professor Janssen, the chief cause for concern is the length of degree courses. "If the Netherlands education system attains the goal of graduates with a shorter period of study," he said, "all these problems would be somewhat alleviated."

The general consensus among Netherlands educational authorities is that a new four-year degree course should be introduced. This would be designed "not to train students for a particular profession but to teach them the scientific method". The Netherlands delegates at the confrontation meeting pointed out, however, that no basic changes in the universities can be made without almost unanimous consent of the universities themselves. 